\title{
The status of seabird colonies on the Cook Islands atoll of Suwarrow
}

\author{
RHYS J. JONES
}

\begin{abstract}
Summary
Suwarrow (Suvorov) atoll is an important seabird breeding site in the central Pacific Ocean. However, it is not protected and is attractive to developers of potentially damaging aquaculture industries. In this paper I report the results of a survey conducted to establish the present status of Suwarrow's seabird colonies and to generate base-line data for measuring the effect of a proposed pearl-farm development. Between late July and early September 2000 the reef islets were surveyed for seabird chick numbers and age-states using a simple sampling method. In addition to Sooty Tern Sterna fuscata, populations of boobies Sula spp., noddies Anous spp., frigatebirds Fregata spp. and tropicbirds Phaethon spp. were assessed. Results showed that bird populations were maintaining levels similar to those from findings of surveys in 1992. Of particular note were globally significant numbers of Lesser Frigatebird Fregata ariel and Red-tailed Tropicbird Phaethon rubricauda. Migratory birds were observed with Bristle-thighed Curlew Numenius tahitiensis regularly seen. The well-being of bird-life on the islets appears to be indirectly proportional to the proximity of human activity, with birds not observed breeding on Anchorage Island - the islet most often visited by people.
\end{abstract}

\section{Introduction}

Suwarrow (Suvorov) atoll is an important central Pacific Ocean breeding area for several species of tropical seabird including Sooty Tern Sterna fuscata, Lesser Frigatebird Fregata ariel, Brown Noddy Anous stolidus, Red-tailed Tropicbird Phaethon rubricauda and boobies Sula spp. The atoll has the only large colonies of Sooty Tern and Brown Booby Sula leucogaster in the Cook Islands (McCormack and Kunzle 1990) and is a breeding site for 9\% of the global Lesser Frigatebird population and $3 \%$ of the global Red-tailed Tropicbird population (Anon. 2001). Migratory birds, such as Bristle-thighed Curlew Numenius tahitiensis and Wandering Tattler Heteroscelus incanus overwinter on Suwarrow and the atoll also provides habitat for coconut crabs and two threatened species of turtle (McCormack 1985).

Suwarrow has yet to be listed as an important bird area (IBA), although it is widely viewed as meeting the necessary criteria used to identify IBAs (A. Tiraa in litt. 2001). Nevertheless, the atoll has no formal protection and recent development proposals, including pearl farming (Anon. 1999a, b) represent significant potential threats to its biodiversity.

A seabird survey conducted during June and July 1992 indicated the following numbers of breeding pairs on Suwarrow's reef islets (in round numbers): 80,000 
Sooty Tern, 250 Greater Frigatebird Fregata minor, 8,500 Lesser Frigatebird, three Masked Booby Sula dactylatra, 95 Brown Booby, 1,50o Red-footed Booby Sula sula, 250 Brown Noddy, and 400 Red-tailed Tropicbird (G. McCormack in litt. 2000, Saul 1992). These populations represent a source of biodiversity in the central Pacific likely to grow in importance as bird populations on other islands diminish due to environmental degradation from development. However, development on Suwarrow itself may have negative impacts on these bird populations, due to the intolerance of such species to noise, imported pests and human interference (Nelson 1980, Furness and Monaghan 1987).

To generate base-line data useful for evaluating the effect of any near-term development and to obtain up-to-date data on Suwarrow's seabird colonies, a chick survey was conducted between July and September 2000. This information will provide base-line data that can be compared with future data for detecting shifts in breeding patterns. This could provide early warning of problems with colony stability and, where due to human activity, corrective measures could be made.

\section{Study area}

Suwarrow $\left(13^{\circ} 14^{\prime} \mathrm{S}, 163^{\circ} \mathrm{O} 5^{\prime} \mathrm{W}\right.$ ) is a remote atoll in the northern Cook Islands (central Pacific Ocean), approximately $800 \mathrm{~km}$ north-west of Rarotonga. The atoll comprises islets and cays (known locally as motu) surrounding a lagoon $80 \mathrm{~km}$ in circumference and $80 \mathrm{~m}$ deep, with one navigable entrance on its north-east perimeter (Figure 1). The islets are composed predominantly of reef-derived limestone and unconsolidated boulder (Woodroffe and Stoddart, 1992) and the four largest islets have densely wooded interiors. The smaller islets and cays presently number 23 and this number varies according to definition and the impact of occasional cyclones. A tropical climate moderated by south-easterly trade winds prevails for most of the year. From November to April the atoll receives higher rainfall due to storms from the north and north-west. Suwarrow lies within the south Pacific cyclone belt and severe storms have occurred, notably in 1914, 1940, 1942, 1967 (Woodroffe and Stoddart 1992) and 1993. Suwarrow has no permanent human population. Visits by private yachts are increasing and the Cook Islands government regularly appoints a caretaker to supervise yacht visits outside the cyclone season. At the time of writing a cyclone shelter was being constructed on Anchorage Island so that a caretaker can be appointed year-round.

\section{Survey method}

Nine breeding seabird species were studied: Sooty Tern, Lesser Frigatebird, Greater Frigatebird, Red-tailed Tropicbird, Brown Booby, Red-footed Booby, Masked Booby, Brown Noddy and Black Noddy Anous tenuirostris. Other migratory species were noted when seen.

Seabird chicks were counted on each islet between late July and early September. Small islets and cays were surveyed in their entirety. The larger islets of Anchorage Island, One Tree Island, Turtle Island, Motu Manu, Motu Tou and Motu Oneone (Figure 1) were surveyed using 20-m transects measured at 100-m 


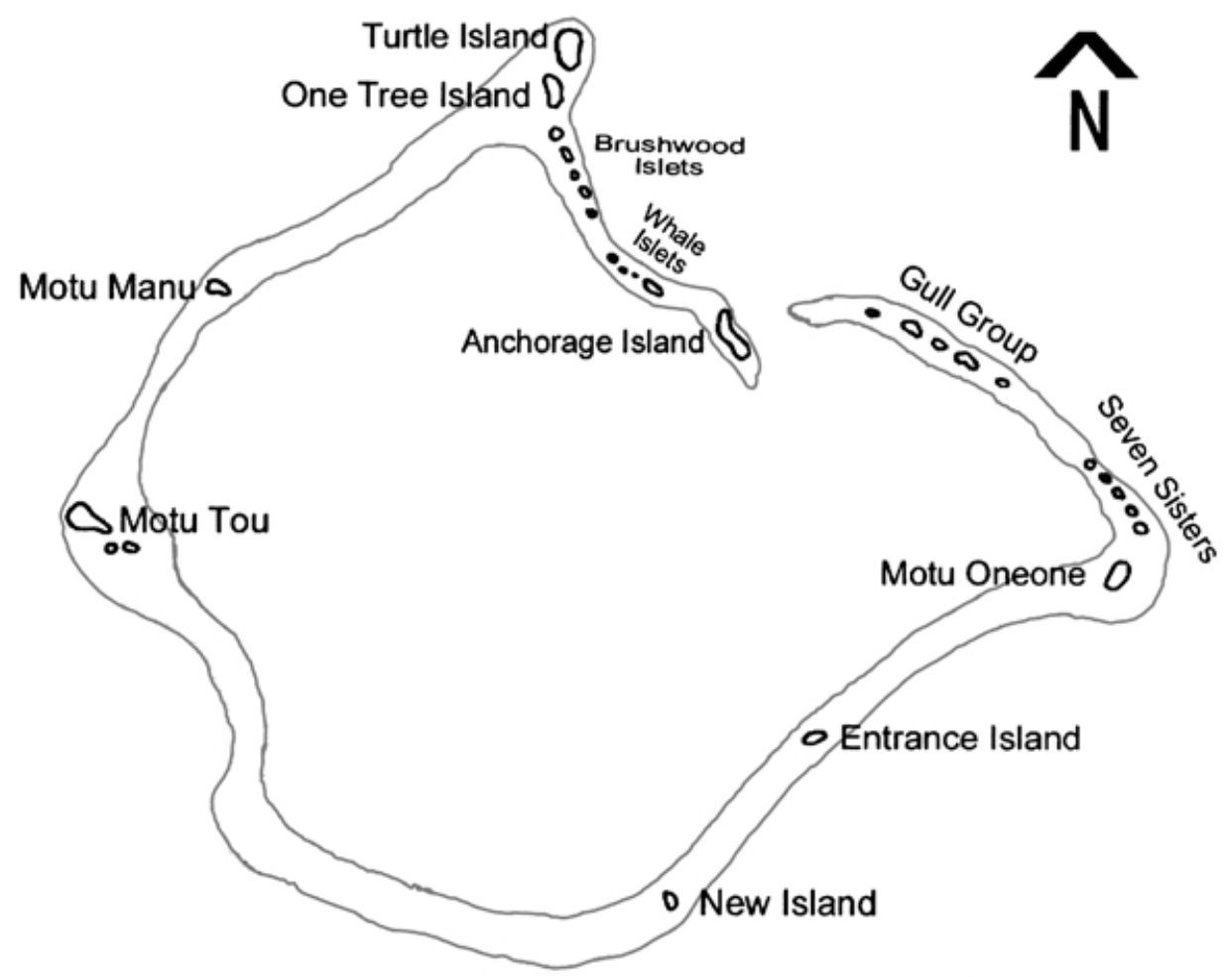

$5 \mathrm{~km}$

Figure 1. Suwarrow atoll with location of reef islets

intervals following a compass bearing. A simple counting system was used based on the method of Kepler $(1969,1978)$ designed for determining the approximate time of egg laying from the extent of plumage development. Briefly, feather development was determined from charts as being one the following stages: egg, naked, down, scapulars, wings/tail or juvenile. Each age-stage reflects time from egg laying, which differs for each species studied. For Sooty Terns, juveniles were further differentiated as either "downy juvenile" or "juvenile" to distinguish between fully feathered juveniles that had no down (many of which were flying) and juveniles with some down remaining about the belly and flanks. Where possible, Red-footed Booby chicks were distinguished as either brown or white morph from juvenile colourings or when the chick was with a parent.

The counting method used in this survey allowed the approximate time of egg laying to be calculated from the stage of chick development. Consequently, only eggs that actually hatched are considered.

Sooty Tern chicks are highly mobile and can be present in large numbers. Chick counting was therefore carried out by choosing a suitable landmark beyond a field of chicks and counting individuals within the field (between observer and landmark). The observer then walked through the field to the next landmark and repeated the process until the study area had been traversed. This 
method was found to be effective because chicks within a field tended to move out of the field to the side rather than forward into the next field. Other groundbased chicks (Brown Noddy, Red-tailed Tropicbird, Masked Booby and Brown Booby) were present in numbers small enough to be counted directly. Treedwelling species (Red-footed Booby, frigatebirds, Black Noddy) were counted directly.

Chick totals for larger islets were calculated from data collected from the 20-m transects. The number of transects surveyed on the larger islets were: Anchorage Island (10), One Tree Island (4), Turtle Island (7), Motu Manu (3) and Motu Oneone (5). Transect totals for each islet were multiplied by five to derive totals for the entire land area. Due to time and tide restrictions Motu Tou was surveyed using six $20-\mathrm{m}$ transects at $200-\mathrm{m}$ intervals only and results were multiplied by a factor of 10 to derive totals for that islet.

Most flying adult male frigatebirds were observed to be Lesser Frigatebird, distinguished from Greater Frigatebird by white patches on the axillaries (Holyoak 1980). However, it was not possible to distinguish confidently between the two species when the adults were on nests without disturbing them. Results are therefore combined under the generic term "frigatebird" though it is likely that the great majority of frigatebirds on Suwarrow were of the lesser species.

\section{Results}

The majority of Sooty Tern chicks were located on One Tree Island $(52,620)$ and Motu Manu (18,830; Table 1). The majority of frigatebird chicks were found on Motu Manu $(3,406)$ and the Gull Group $(1,344)$. Brown Booby chicks were found mainly on Motu Oneone and also on Brushwood 1, Motu Kena (the two small islets immediately south of Motu Tou, see Figure 1) and the Seven Sisters. Redtailed Tropicbird, Red-footed Booby and Brown Noddy chicks were distributed over most islets. One colony of 21 Masked Booby chicks was found on the Seven Sisters Islands and one colony of 70 Black Noddy was found in the interior of Motu Tou.

The great majority (> 99\%) of Sooty Tern chicks were downy juveniles or juveniles (Table 2) indicating that egg laying had occurred during April, approximately four months before the survey. Frigatebird young were represented from egg stage $(30 \%)$ through all stages to juvenile (14\%) indicating that egg laying occurred throughout the preceding eight months (Table 2). A frigatebird colony on Motu Manu (separate results not tabulated) contained a larger proportion of chicks at egg stage $(36 \%)$ compared with Suwarrow's second major frigatebird colony in the Gull Group (17\%), which conversely had a larger proportion of juveniles (19\% versus $11 \%$ ).

The majority of Red-tailed Tropicbird chicks were present as eggs (34\%) or juveniles $(47 \%)$ indicating two peaks in egg laying (Table 2). Based on an average survey date of 15 August, the first peak occurred after the beginning of July, within six weeks of the survey, represented by $34 \%$ of all tropicbird chicks counted as eggs. A second peak, represented by juveniles, would have originated from eggs laid between mid-March and late April, between 14 and 20 weeks pre-survey.

The majority (74\%) of Red-footed Booby chicks (both morphs) were between 


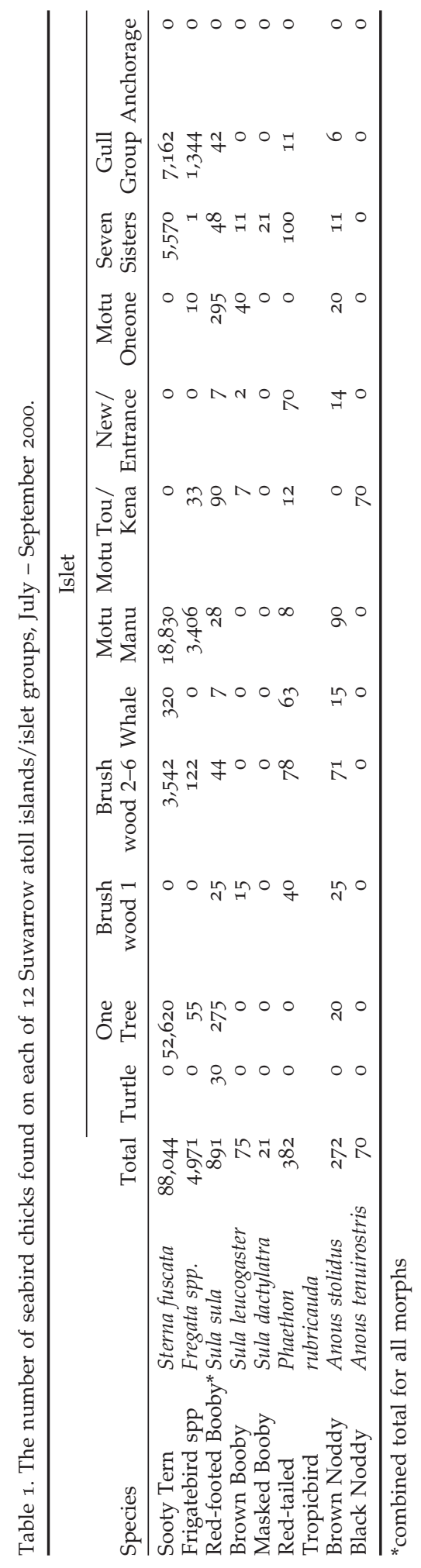




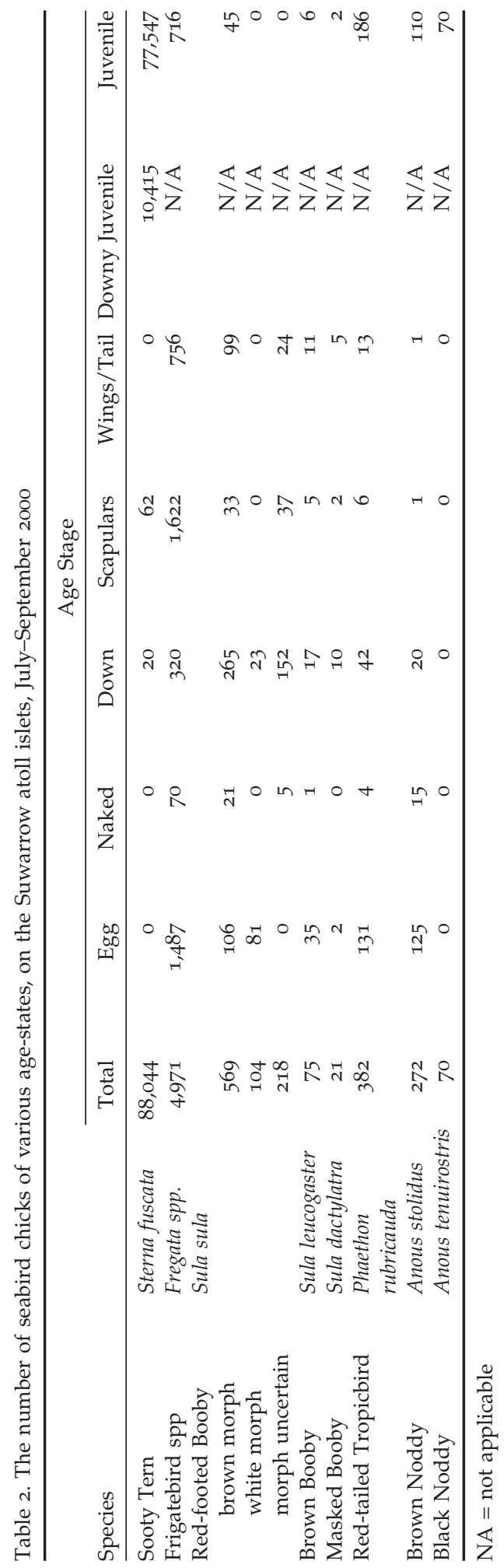


egg and downy stages and represent one major laying peak between mid-May and late July (Table 2). Approximately half (47\%) of Brown Booby offspring were present as eggs and would have been laid from the beginning of July onwards. The remaining Brown Booby chicks (53\%) were present across age-states from naked to juvenile indicating that the adults had been breeding for at least the previous six months. Masked Booby offspring were represented by egg stage $(10 \%)$ to juvenile stage (10\%), with a larger number of downy chicks $(48 \%)$, indicating that breeding had occurred over the previous six months with more eggs laid in mid-May.

The majority of Brown Noddy chicks were present as eggs (46\%) or juveniles (40\%; Table 2) representing peaks in egg laying during the four weeks before survey, from mid-July to mid-August, and also during April. All Black Noddy chicks observed were juveniles indicating eggs laid during April. The number of Black Noddy chicks present as eggs is unclear due to the difficulty of inspecting the contents of nests high in trees.

Bristle-thighed Curlews were frequently seen on beach areas of most islets, either singly or in groups of up to 10 individuals. Wandering Tattler were occasionally observed and also Reef Heron Egretta sacra.

\section{Discussion}

Black and Brown Noddy chicks were found to be well camouflaged and it is therefore likely that numbers of these species on Suwarrow are somewhat underrepresented in this report. Similarly, Sooty Tern chicks were observed to be highly mobile and reported numbers may be slightly higher or lower than actual numbers.

Birds tended to nest in or amongst low trees and shrubs near beach areas, particularly pemphis Pemphis acidula and beach heliotrope Tournefortia argentea. The interior of the larger islets of Whale Island, Motu Tou and Motu Oneone were largely devoid of nesting birds (an exception was Black Noddy which was observed nesting high in Tou Cordia subcordata trees in the dense interior of Motu Tou) and hence total bird numbers for large islets were not necessarily in proportion to their size compared with numbers on smaller islets. Of particular note was that no chicks of any species were seen on Anchorage Island, Suwarrow's largest motu and the islet most affected by humans. This was perhaps not an unexpected finding because Sooty Terns, while historically breeding in large numbers on Anchorage Island (Neale 1966), are prone to abandon breeding grounds when human activity is close (Nelson 1980). Furthermore, breeding is likely to be further discouraged on Anchorage Island by the presence of two domestic cats. These had apparently been left by a previous caretaker to control rats. Rats were not observed on Anchorage Islet, but the discovery of two piles of Noddy feathers suggested that the cats had killed birds. The only rats seen on Suwarrow were three small Polynesian rats ("Kiore") observed on Motu Kena. Historically, rats have been observed on Suwarrow from the time of the atoll's European discovery in 1814 (Cowan 1936).

When Neale (1966) reported Sooty Terns on Anchorage Island he observed that egg laying occurred during November and December. The present study found that nearly all Sooty Tern chicks originated from eggs laid in April 
reflecting the propensity for these birds to nest more than once per year. Sooty Terns take approximately 20-22 weeks to mature from eggs to adults so at the time of survey there would be no chicks remaining from eggs laid in the previous November-December period. Since nearly all chicks observed were juveniles, significant egg laying had probably not occurred since April. Sooty Tern chick numbers for Suwarrow overall $(88,044)$ were similar to numbers reported in the 1992 survey $(80,000)$.

Some variation in egg laying was observed between Suwarrow's frigatebird colonies. For example, the largest colony was found on Motu Manu and contained 3,400 chicks (Table 1). Approximately $36 \%$ of these chicks were present as eggs whereas only $17 \%$ of chicks in Suwarrow's second frigatebird colony (located in the Gull Group) were represented as eggs. Frigatebird eggs take approximately seven weeks to hatch so it is likely that egg laying started up to one month earlier in the Gull Group colony. This view is supported by the Gull Group colony containing a larger proportion of juveniles than Motu Manu ( $19 \%$ compared with $11 \%$ ) indicating that egg laying started earlier in the Gull Group colony. In 1992 nearly all frigatebird nests (>99\%) were located in the Gull Group (Saul 1992).

This survey presents base-line data describing the state of Suwarrow's seabird colonies between late July and early September 2000. The data support the view that Suwarrow is an important site for biodiversity in the central Pacific Ocean. In particular, Suwarrow's Sooty Tern, frigatebird and Red-tailed Tropicbird colonies are of international significance. The atoll's importance as a seabird breeding colony is likely to increase as similar sites elsewhere become degraded through development or other human impact. These survey data indicate that chick numbers for each species on Suwarrow are similar to results obtained in 1992 (with the exception of the Black Noddy, which was not observed breeding during the 1992 survey). At the time of writing a proposal to develop pearl farms on Suwarrow had been rejected by the Cook Islands government after sustained lobbying by environmental groups. Any future development on Suwarrow is likely to be permitted only if there is no significant impact on seabird colonies. The results of this survey provide base-line data for making such assessments.

\section{Acknowledgements}

I would like to thank Cathy Fitzgerald for her support for this project and assistance in data collection. Thanks also to the Cook Islands government for permitting this work, the Cook Islands Environmental Service and Gerald McCormack (Cook Islands Natural Heritage Project) for providing methodology and helping us obtain the necessary permits; and to Matt Sponer for providing passage aboard his yacht Mary Francis.

This project was funded with assistance from the Cook Islands National Biodiversity Project and the Pacific Development Trust (New Zealand).

\section{References}

Anon. (1999a) Pacific Islands Report, March 3: Environmental study favours pearl farming on Suwarrow Atoll, Cook Islands. University of Hawaii at Manoa, Hawaii: Pacific Islands Development Program. 
Anon. (1999b) Final environmental impact assessment for pearl farming development in Suwarrow atoll, Cook Islands, South Pacific. Black Pearls Inc., PO Box 525, Holualoa, Hawaii.

Anon. (2001) Important Cook Islands seabird breeding site under threat. Cambridge, U.K.: BirdLife International (News release, 5 March).

Cowan, J. (1936) Suwarrow gold and other great stories of the South Seas. London: Jonathan Cape.

Furness, R.W. and Monaghan, P. (1987) Seabird ecology. New York: Chapman and Hall.

Holyoak, D.T. (1980) Guide to Cook Island birds. New York: D.T Holyoak.

Kepler, C.B. (1969) Breeding biology of the blue-faced booby (Sula dactylatra personata) on Green Island, Kure Atoll. Pub. Nuttall Orn. Club, 8.

Kepler, C.B. (1978) The breeding ecology of seabirds on Monito Island, Puerto Rico. Condor 80: $72-87$.

McCormack (1985) Suwarrow National Park. Report to the Secretary of Internal Affairs. Rarotonga: Cook Islands Government.

McCormack, G., Kunzle, J. (1990) Seabirds of Takutea and Suwarrow. Rarotonga: Cook Islands Conservation Service (PO Box 371, Rarotonga. ISBN 982-222-001-4).

Neale, T., (1966) An island to oneself. London: Collins.

Nelson, B. (1980) Seabirds: their biology and ecology. London: Hamlyn.

Saul, E., (1992) Suwarrow bird survey. Rarotonga: Cook Islands Natural Heritage Project. (Unpubl. report.)

Woodroffe, C.D. and Stoddard, D.R. (1992) Substrata specificity and episodic catastrophe: constraints on the insular plant geography of Suwarrow atoll, northern Cook Islands. Atoll Res. Bull. 362: 1-19.

RHYS J. JONES

AgResearch Ltd, Private Bag 3123, Hamilton, New Zealand. Correspondence to: PO Box 12275, Chartwell, Hamilton, New Zealand.

Received 4 April 2001; revision accepted 8 August 2001 
